\title{
Developing a Low-Cost Salinity Sensor Using Locally Sourced Materials
}

\author{
${ }^{1}$ Okunlola B.A., ${ }^{2}$ Ewetumo T., ${ }^{3}$ Okogbue E. C., ${ }^{4}$ Olabanji O. M. \\ ${ }^{1,3}$ Department of Meteorology and Climate Science, the Federal University of Technology, Akure, Nigeria \\ ${ }^{2,4}$ Department of Physics, the Federal University of Technology, Akure, Nigeria \\ E-mail: ${ }^{1}$ baokunlola@ futa.edu.ng, ${ }^{2}$ ewetheo66@gmail.com, ${ }^{3}$ ecokogbue@ futa.edu.ng, ${ }^{4}$ omolabanji@ futa.edu.ng
}

\begin{abstract}
We report the design and construction of a locally constructed hydro-meteorological sensor for surface and underwater vehicles. This salinity sensor consists of four electronics units: the power, input (sensor), gain (amplifies the output signal), and output units. Each unit/block utilizes various low-power integrated circuits. The calibration equation of the salinity sensor was 1055.6 $\exp ^{-1.062} \mathrm{ml} / \mathrm{mg} / \mathrm{volt}$ (correlation coefficient $\mathbf{r}=$ 0.9897). The performance and the coefficient of efficiency of the constructed sensor were compared with a standard sensor, showing the Mean Bias Error (MBE), Root Mean Square Error, and Standard Deviation of $\mathbf{- 0 . 5 5 3 5}, \mathbf{1 . 3 8 2 5}$, and $3.4839 \mathrm{ml} / \mathrm{mg}$, the error margins were relatively small, indicating an excellent performance by the sensor. However, the negative MBE suggests a slight underestimation of the standard. Conclusively, the sensor is efficient in hydro-meteorological studies, capable of monitoring solution conductivity and measuring salinity (and total dissolved salt) in the ocean or brackish water.
\end{abstract}

Keywords: PVC, Braze rods (electrode), Light-Emitting Diode (LED), Salt, Digital multimeter and manual weighing scale.

\section{INTRODUCTION}

In 1865, Forchhammer introduced the term salinity, dedicating his research to determining individual components of sea salt rather than the total salinity. During his study, he discovered that the ratio of major components in seawater samples from various locations around the globe was constant. This constant ratio was later named Forchhammer's Principle of Constant Proportions [9]; [11] sequel to his studies at the end of the nineteenth century, William Dittmar experimented on several methods to analyze the chemical composition of seawater [18]. Thormas 2014 discovered that the Dittmar methods were much superior and extremely precise than others [7]; [14]. Through silver nitrate precipitation of the chloride content from sea water by adding a solution of silver nitrate to the aqueous solution of chloride ions, Dittmar determined the chloride content and verified the credibility of the process by comparing it with synthetic seawater [3]. He later analyzed seventy seven samples from around the world, taken during the Challenger Expedition. He gathered that although the salinity of the sea waters differs, the Forchhammer's Principle of Constant Proportions was exact [17]; [19].

Salinity determines the type of organisms and plants that can thrive in a water body. Any slight change in salinity can induce stress or death to the inhabiting organisms, thereby disrupting the local and broader ecosystems [12]; [10]. The salinity sources in freshwater include urban and rural runoff from industry, sewage, agriculture, and storm water. An increase in salinity levels can also end the existence of vegetation due to the rise in the water table.

The region within the tidal restriction of rivers that move into the sea experiences variation in salinity between lower and higher tides [16]; [13]. In discharge, there is usually a moderate variation in salinity, as freshwater entering the estuary from tributaries meets the seawater moving in from the ocean.

Human attempts to measure seawater saltiness originated in ancient Greece. However, the efficiency of the original methods was incipient, with low sensitivity and repeatability [1]. Later, more precise techniques were developed viz. evaporation [2], solvent extraction [4], and precipitation [5]; [15].

Several salinity meters were stand in the way of one another when placed in the same liquid. The degree of interference depends on several factors, including the combination of sensors used, the interface, etc. This design aims to solve the problem associated with the ocean salinity measurement sensor in marine research. Today, salinity sensors are very costly in the international market and it not easy to maintain when it is faulty.

\section{METHODOLOGY}

The salinity measurement was carried out in the Chemical Oceanography Laboratory of The Federal University of Technology, Akure, Nigeria. Thesalinity sensor designed measures the current flow in between the twobraze rods 
ISSN (online): 2581-3048

electrodes. The amount of current is proportional to the concentration of ions in thesolution. The measured current is proportional to the conductivity of the solution as the direct voltage is applied across the electrodes [8].

\subsection{Electrical design}

Two braze rods were used to transmit the salinity level to LED output indicators. The sensor measures conductance in the electrical system. When the saltwater has a resistance equal to the current that applied through the saltwater and resistors, it causes the differential voltage across the input, and the comparator circuit is used by an op-amp IC, the LED Display Level Meters.

The output voltage must be close to zero when salt content is not detectable., i.e., the design sensor should perform as a salinity measuring device rather than a $\mathrm{pH}$-sensing device. Thus, the salinity sensor consists of two $40 \mathrm{~mm}$ length, differential amplifiers, about $5 \mathrm{~mm}$ apart, and a $2.5 \mathrm{~V}_{\text {ref }}$ reference. At the non-inverting input of the differential amplifier, an alternator resistance was inserted in water, $\mathrm{R}_{1}$, $R_{2}$, and $R_{3}$, (1). The voltage developed across $R_{3}$ when compared with voltage constant set at inverting input of the amplifier. Pot $V_{R 1}$ calibrates the salinity level. $R_{4}$ and $R_{3}$ obtain the amplified gain can be 5 volts. The output voltage of the differential amplifier is shown in Figure 1 [6].

$$
V_{O}=\frac{R_{3}}{R_{4}}\left(V_{n o n-i n v}-V_{i n v}\right)
$$

The digital electronic system for the salinity sensor is depicted in Figure 1.

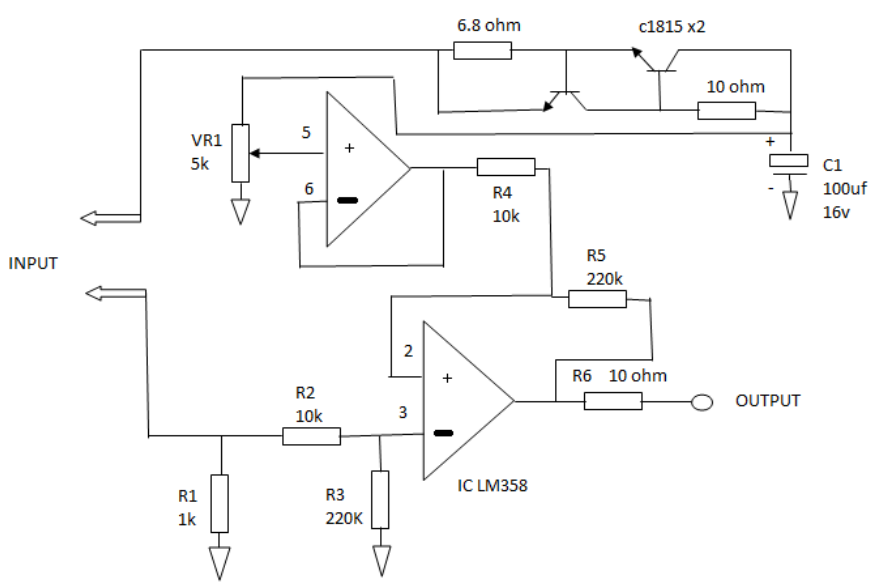

Figure 1: A diagram showing the circuit design of the salinity sensor (Generated using PCB123 Electronic Design Software)

The power supply circuit provides 5 volts for the system using Linear Monolithic (LM) 7805. Due to the high sensitivity of digital devices to voltage, an internal DC power supply is used. The first element in the unit is a three-terminal adjustable regulator, bridge rectifier, used as a network of IN4007 diodes. Fluctuations and ripples superimposed on the rectifier DC voltage are filtered out by $220 \mu \mathrm{F}, 25 \mathrm{~V}$, and 0.1 $\mu \mathrm{F}$ capacitors, schematically shown in Figure 2.

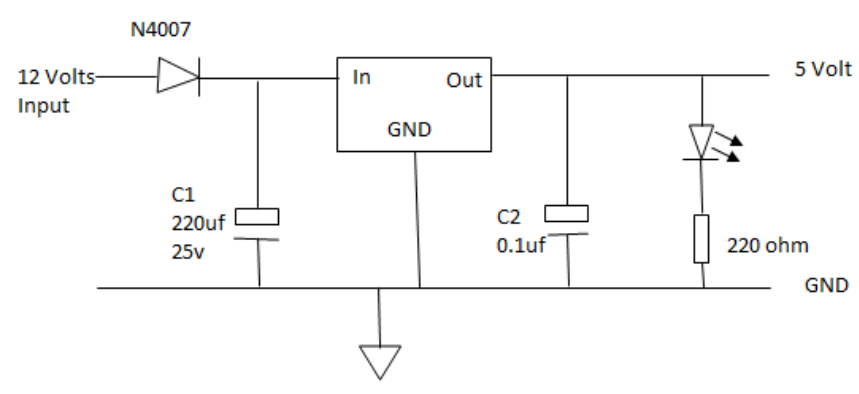

Figure 2: Power Supply Circuit Diagram

A 5-in-1 auto-ranging digital multimeter was used as an output display unit with a frequency measure of 0 to 20 volts.

\subsection{Mechanical design}

The PVC pipe was used for the sensor's body because of its low-cost and corrosion-resistant merits and the braze two rods used as sensing devices shows in Figure 3.

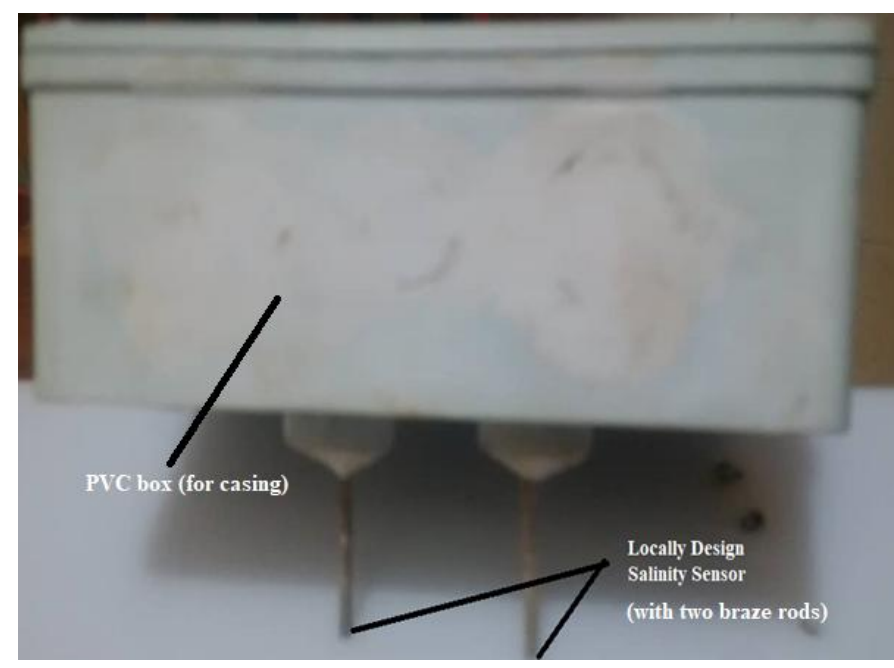

Figure 3: Designed Salinity Sensor

\subsection{Calibration}

The novel sensor was calibrated for accuracy and precision against a standard one at the Department of Physics, the Federal University of Technology Akure. Nigeria. (Figure 4). The following were the steps taken for the calibration of the new sensor.

1. The salinity sensor was inserted in ordinary (non-saline, reference) water. The RV1 was adjusted at differential output close to zero. The derived value at Figure 4 is 
ISSN (online): 2581-3048

Volume 5, Issue 8, pp 102-106, August-2021 https://doi.org/10.47001/IRJIET/2021.508017

deducted from output measured after adding water of various salinities.

2. The standard salinity sensor and the newly fabricated one were used to measure the salinity of the water samples. Their respective salinity values are listed in Table 1 . The relation and characteristic equation developed was program inside the micro-controlled.

The precision and accuracy of the developed sensor against the standard were computed after series of experiments and measurements (Figure 5).

The derived standard calibration curve is depicted in Figure 6.

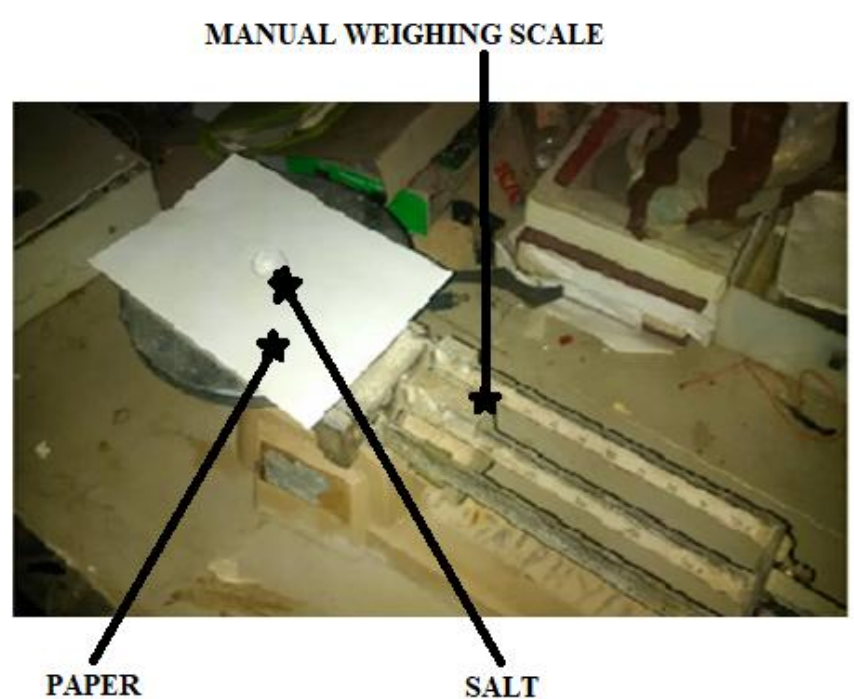

Figure 4: Manual Weighing Balance with Salt at Physics Laboratory Department FUTA during the Design Salinity Sensor Calibration

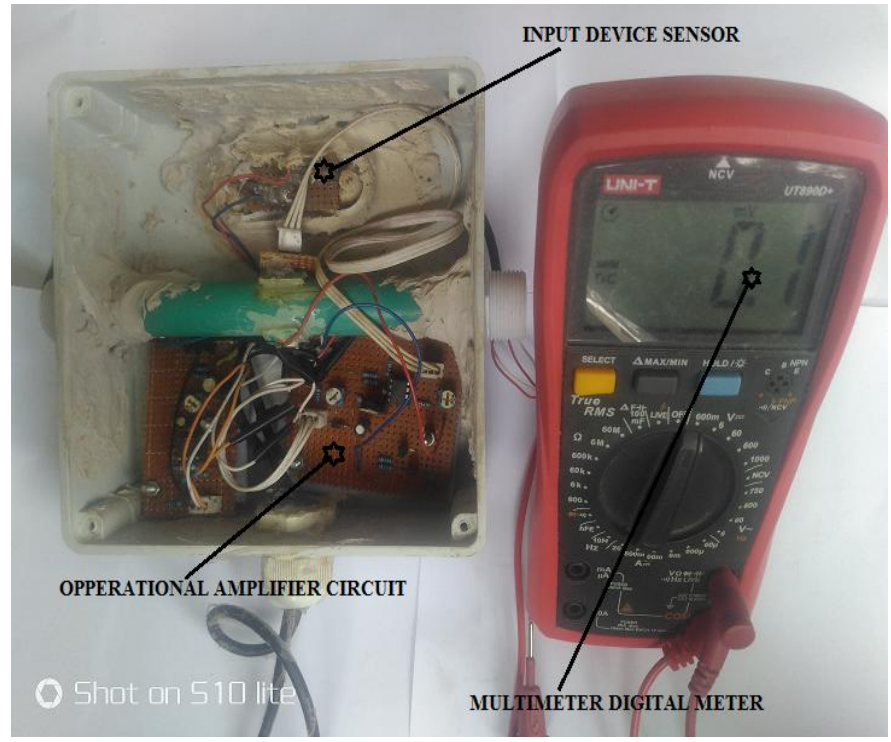

Figure 5: Laboratory calibration of Design Salinity Sensor at Physics Department FUTA
Table 1: Turbidity calibration table

\begin{tabular}{|l|l|l|}
\hline Volume of Water & 200 ml & 375 \\
ml \\
\hline $\begin{array}{l}\text { Output Voltage } \\
(\text { V) }\end{array}$ & $\begin{array}{l}\text { Amount of salt } \\
(\mathrm{mg})\end{array}$ & $\begin{array}{l}\text { Volume of water/unit } \\
\text { mass of salt }(\mathrm{ml} / \mathrm{mg})\end{array}$ \\
\hline 0.47 & 0.07 & 2703 \\
\hline 0.83 & 0.19 & 1075 \\
\hline 1.13 & 0.23 & 885 \\
\hline 1.57 & 0.30 & 658 \\
\hline 1.76 & 0.35 & 568 \\
\hline 2.24 & 0.41 & 490 \\
\hline 2.34 & 0.47 & 427 \\
\hline 3.00 & 0.60 & 333 \\
\hline
\end{tabular}

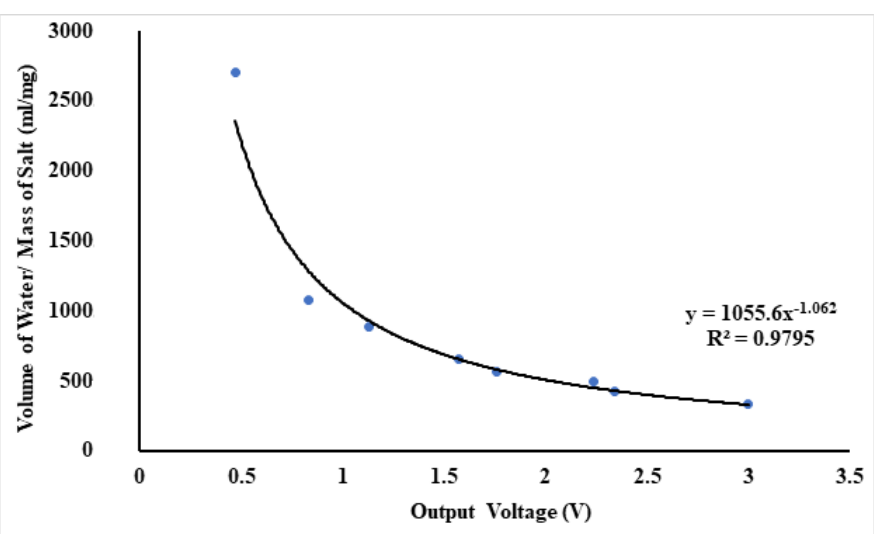

Figure 6: The calibration graph of designed salinity sensor

\section{RESULTS AND DISCUSSIONS}

This chapter shows the result so far was done and the outputs are as followed. The data analysis obtained from designed salinity sensor, this includes statistical comparison of the readings from the new sensor.

\subsection{Data Analysis}

Correlation coefficient (R) Figure 6, root-mean-square error (RMSE)(2), mean-bias error (MBE) E (3), and standard deviation (SD) (4) were employed for statistical comparison between the readings of the new sensor and that of the reference material [20].

$$
\begin{aligned}
R M S E & =\sqrt{\frac{\sum\left(X_{m s s, i}-X_{m c s, i}\right)^{2}}{n}} \\
M B E & =\left[n^{-1} \sum_{i=1}^{n}\left|e_{i}\right|=\bar{P}-\bar{O}\right] \\
S D & =\sqrt{\frac{\sum(x-\bar{x})^{2}}{N-1}}
\end{aligned}
$$


The results of the MBE, RMSE, STDEV, and R obtained from the comparison of the constructed sensor against the reference were $-0.5535,1.3825,3.484$, and 0.9897 , respectively. The $\mathrm{R}$ value shows a very good association between the data obtained from the constructed salinity sensor and the reference material (0.9897). Also, we observed that the error margin (MBE, RMSE, and STDEV) between the constructed sensor and the standard was relatively small, confirming an excellent performance of the new sensor.

\section{CONCLUSION}

A salinity sensor has been designed, constructed and calibrated. The data obtained from the constructed sensor was compared with a standard sensor at Physics Laboratory, the Federal University of Technology, Akure Nigeria for indoor calibration. The designed salinity measuring sensor gave a calibration coefficient equation 1055.6exp-1.062 ml/mg/volt (Figure 6) with regression co-efficiency of 0.9897 , the regression co-efficiency values shown that there is very good associations between the data obtained from the designed sensor. The constructed sensor was found to be viable and capable of field deployment and it can be constructed locally using available sourced materials.

\section{ACKNOWLEDGEMENT}

This work was financially supported by the year 20162017 the Merged Tertiary Education Trust Fund (TETFund) Research Projects Intervention Grant.

\section{REFERENCES}

[1] Booij, K., Robinson, C. D., Burgess, R. M., Mayer, P., Roberts, C. A., Ahrens, L., et al. (2016). Passive sampling in regulatory chemical monitoring of nonpolar organic compounds in the aquatic environment. Environ. Sci. Technol. 50, 3-17. doi: 10.1021/acs.est.5b04050.

[2] Griffith, J. F., and Weisberg, S. B. (2011). Challenges in implementing new technology for beach water quality monitoring: lessons from a California demonstration project. Mar. Technol. Soc. J. 45, 65-73. doi: 10.4031/MTSJ.45.2.13.

[3] Kröger, S., Parker, E. R., Metcalfe, J. D., Greenwood, N., Forster, R. M., Sivyer, D. B., et al. (2009). Sensors for observing ecosystem status. Ocean Sci. 5, 523-535. doi: 10.5194/os-5-523-2009.

[4] Lim, J., and Choi, M. (2015). Assessment of water quality based on Landsat 8 operational land imager associated with human activities in Korea. Environ. Monit. Assess. 187:384. doi: 10.1007/s10661-0154616-1.
[5] Mills, G., Fones, G. R., and Kröger, S. (2014). "In-situ sensors for monitoring the marine environment," in Measurement, Instrumentation and Sensors Handbook, eds J. G. Webster and H. Eren (Boca Raton, FL: CRC Press Taylor \& Francis Group), 71-72.

[6] Murphy, K., Sullivan, T., Heery, B., and Regan, F. (2015). Data analysis from a low-cost optical sensor for continuous marine monitoring. Sens. Actuat. B Chem. 214, 211-217. doi: 10.1016/j.snb.2015.02.023.

[7] Oinonen, S., Hyytiäinen, K., Ahlvik, L., Laamanen, M., Lehtoranta, V., Salojärvi, J., et al. (2016). Costeffective marine protection - a pragmatic approach. PLoS ONE 11:e0147085. doi: 10.1371/journal.pone.0147085.

[8] Peck, M. A., Arvanitidis, C., Butenschön, M., Canu, D. M., Chatzinikolaou, E., Cucco, A., et al. (2016). Projecting changes in the distribution and productivity of living marine resources: a critical review of the suite of modelling approaches used in the large European project VECTORS. Estuar. Coast. Shelf Sci.doi: 10.1016/j.ecss.2016.05.019. [Epub ahead of print].

[9] Radu, A., Anastasova, S., Fay, C., Diamond, D., Bobacka, J., and Lewenstam, A. (2010). Low cost, calibration-free sensors for in situ determination of natural water pollution. IEEE Sensorsdoi: 10.1109/ICSENS.2010.5690357.

[10] Roy, H. E., Pocock, M. J. O., Preston, C. D., Roy, D. B., Savage, J., Tweddle, J. C., et al. (2012). Understanding Citizen Science and Environmental Monitoring: Final Report on Behalf of UK Environmental Observation Framework..

[11] Sendra, S., Parra, L., Lloret, J., and Jiménez, J. M. (2015). Oceanographic multisensor buoy based on low cost sensors for posidonia meadows monitoring in Mediterranean Sea. J. Sensors 2015:920168. doi: $10.1155 / 2015 / 920168$.

[12] Shutler, J. D., Warren, M. A., Miller, P. I., Barciela, R., Mahdon, R., Land, P. E., et al. (2015). Operational monitoring and forecasting of bathing water quality through exploiting satellite Earth observation and models: the AlgaRisk demonstration service. Comput. Geosci. 77, 87-96. doi: 10.1016/j.cageo.2015.01.010.

[13] Su, T.-C., and Chou, H.-T. (2015). Application of multispectral sensors carried on unmanned aerial vehicle (UAV) to trophic state mapping of small reservoirs: a case study of tain-pu reservoir in kinmen, Taiwan. Remote Sens. 7, 10078-10097. doi: 10.3390/rs70810078.

[14] Thomsen, P. F., Møller, P. R., Sigsgaard, E. E., Knudsen, S. W., Jørgensen, O. A., and Willerslev, E. (2016). Environmental DNA from seawater samples correlate with trawl catches of subarctic, deepwater 
fishes. $\quad P L O S \quad O N E \quad$ 11:e0165252. doi: 10.1371/journal.pone.0165252.

[15] UNEP (2016). Marine Plastic Debris and Microplastics - Global Lessons and Research to Inspire Action and Guide Policy Change. Nairobi.

[16] Van der Molen, J., Ruardij, P., and Greenwood, N. (2016). Potential environmental impact of tidal energy extraction in the Pentland Firth at large spatial scales: results of a biogeochemical model. Biogeosciences 13, 2593-2609. doi: 10.5194/bg-13-2593-2016.

[17] Woody, C., E. Shih, J. Miller, T. Royer, L.P. Atkinson, R.S. Moody, 2000. Measurements of Salinity in the Coastal Ocean: A Review of Requirements and Technologies. Marine Technology Society Journal, 34(2), 26-33.

[18] William J. W. (1974). The development of the chlorinity/salinity concept in oceanography. Elsevier Oceanography SeriesVolume 7, 1974, Pages 105-133. https://doi.org/10.1016/S04229894(08)70980-2.

[19] Wright, S., Hull, T., Sivyer, D. B., Pearce, D., Pinnegar, J. K., Sayer, M. D. J., et al. (2016). SCUBA divers as oceanographic samplers: The potential of dive computers to augment aquatic temperature monitoring. Sci. Rep. 6:30164. doi: 10.1038/srep30164.

[20] Yokota, F., and Thompson, K. M. (2004). Value of information analysis in environmental health risk management decisions: past, present, and future. Risk Anal. 24, 635-650. doi: 10.1111/j.0272-4332.2004. 00464.x.

\section{AUTHORS BIOGRAPHY}

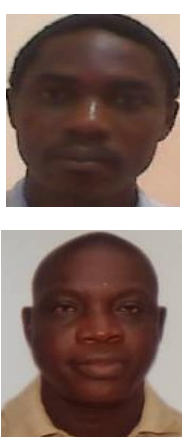

Okunlola, Babatunde Abraham is currently pursuing his Doctorate degree program in Marine Meteorology in The Fedral University of Technology, Akure. Ondo State. E-mail: baokunlola@futa.edu.ng

Ewetumo, Theophilus is pursuing Professorship degree in electronics physics in The Federal University of Technology, Akure. Ondo State E-mail: ewetheo66@gmail.com

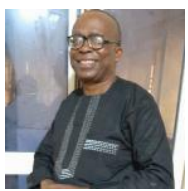

Prof. OKOGBUE, Emmanuel Chilekwu, he is a Prof. of Meteorology and Climate Science and Director, Centre for Continuing Education at the Federal University of Technology, Akure Ondo State Nigeria.

Background: He specializes in the area of Atmospheric Radiation and lower atmospheric processes, climate change, agriculture meteorology and energy.

Education: Ph.D, M.Phil, M.Sc, B.Sc.

E-mail: ecokogbue@ futa.edu.ng

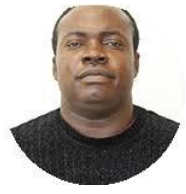

Dr. OLABANJI, Olayinka Mohammed, he is a Lecturer I in the department of Mechanical Engineering department the Federal University of Technology, Akure Ondo State Nigeria.

Education: (A) Ph.D. (Industrial Engineering). (B) M. Eng. (Mechanical Engineering). (C) B. ENG. (Mechanical Engineering) (D) National Diploma (Mechanical Engineering).

Background: (A) The Tshwane University Of Technology, Pretoria West South Africa. (B) The Federal University Of Technology, Akure Ondo State. (C) The Federal Polytechnic Bida, Niger State (D) Egan High School, Egan Lagos. E-mail: omolabanji@futa.edu.ng

\section{Citation of this Article:}

Okunlola B.A., Ewetumo T., Okogbue E. C., Olabanji O. M., "Developing a Low-Cost Salinity Sensor Using Locally Sourced Materials" Published in International Research Journal of Innovations in Engineering and Technology - IRJIET, Volume 5, Issue 8, pp 102-106, August 2021. Article DOI https://doi.org/10.47001/IRJIET/2021.508017 